\title{
PENGEMBANGAN BAHANAJAR MATEMATIKA KELAS IV BERBASIS KURIKULUM 2013 DI SDN KUNCIRAN 7 KOTA TANGERANG
}

\author{
${ }^{1}$ Nur Karmilah, ${ }^{2}$ Een Unaenah, ${ }^{3}$ Erdhita Oktrifianty \\ 1,2,3 Universitas Muhammadiyah Tangerang \\ NurKarmilah.69@gmail.com eenuna@gmail.com erdhita_dta@ $\underline{\text { etmail.com }}$
}

\begin{abstract}
Abstrak
Penelitian pengemban gan ini bertujuan untuk mengetahui langkah-langkah untuk mengha silk an bahan ajar matematika berbasis kurikulum 2013, dan untuk mengetahui kualitas bahan ajar berdasarkan a spek kevalidan dan aspek kepraktisan. Model yang digunakan dalampenelitian ini mengacu pada pendeka tan penelitian dan pengembangan dengan tiga tahap, yaitu studi pendahuluan, pen gembangan produk dan pengujian produk. Subjek penelitian ini a dalah bahan ajar matematika berbasis ku rikulu m 2013 pada materipengumpulan dan penyajian data. Instrumen yang digunakan unt uk mengukurkualitas bahan a jar yang dikembangkan dalam penelitian ini a dalah lembar penilaian a hli materi da n lembar penila ian ahli media untuk a spek kevalidan, serta lembar penila ian ahli pendidikan dan angket re sp on peserta didik untuk aspek kepraktisan. Kualitas kevalidan bahan ajar dinilai dari a spek materi mendapatkan nila i $60 \%$ yang menunjukkan bahan ajar hasil pengembangan valid dengan kriteria valid dan dari a spek media mendapatkan nilai $85 \%$ yang menunjukkan bahan ajar hasil pengembangan valid dengan criteria cukup valid. Kualitas kepraktisan bahan ajar berdasarkan lembarpenilaian ahli pendidikan menda patka n nila $\mathrm{i}$ 96\% yang menunjukkan bahan ajar hasil pengembangan memiliki kualitas praktis dengan kriteria sangat valid da n berdasarkan angketrespon peserta didik diperoleh nilai $81 \%$ y ang menunjukkan bahan a jar hasil pen gem bangan memiliki kualitas praktis dengan kriteria sangat praktis.
\end{abstract}

Kata kunci :Pengembangan Bahan Ajar Matematika, Kurikulum 2013

\begin{abstract}
This development research aims to find out the steps to produce 2013 curriculum-based mathematics tea ching materials, and to find out the quality of teaching materia ls based on validity and practical a spects. The modelused in this study refers to the research and development approach with three st ages, namely a preliminary study, product development and product testing. The subject of this research is 2013 curriculum-based mathematics teaching materialon data collection and presentation. The in strument s used to measure the quality of teaching materials developed in this study were material expert a ssessment sheets and media expert assessment sheets for validity a spects, a s well a s education ex pert a s ses s ment sheets and student questionnaire responses for practical a spects. The quality of the validity of the teaching materials was a ssessed from the material a spect to get a value of $60 \%$ which shows the results of the tea ching materials were valid with valid criteria and from the media aspect the value was $85 \%$ which showed the teaching materia ls from the development results were valid with quite valid criteria. The qua lity of practicality of teaching materials based on theeducation expert a ssessment sheet gets a value of $96 \%$ which shows the results of teaching materials have a practicalquality of deve lopment with very valid criteria and based on questionnaires respon ses of students obtained $81 \%$ value indicating the result s of teaching material development has practical qualities with very practical criteria.
\end{abstract}

Keywords: Development, Mathematics Teaching Material, 2013 Curriculum. 


\section{PENDAHULUAN}

Kurikulum merupakan rencana ataupun program tertulis yang mengarahkan seluruh proses pembelajaran dan menjadi ujung tombak dalam pencapaian tujuan pendidikan. Kurikulum menjadi syarat mutlak bagi pendidikan di sekolah sehingga kurikulum merupakan bagian yang tidak dapat dipisahkan dari pendidikan. Kurikulum 2013 dianggap mampu menerapkan pembelajaran yang sesuai dengan kebutuhan siswa sekolah dasar.

Sebagaimana yang dirtuangkan dalam Peraturan Pemerintah Nomor 19 Tahun 2015 tentang Standar Nasional Pendidikan Bab IV Pasal 20 menyatakan bahwaPerencanaan proses pembelajaran meliputi silabus dan rencana pelaksanaan pembelajaran yang memuat sekurang kurangnya tujuan pembelajaran, materi ajar, metode pengajaran, sumber belajar, dan penilaian hasil belajar.

Berdasarkan Peraturan Pemerintah tersebut maka dalam kegiatan belajar mengajar memerlukan bahan ajar yang ideal yang dapat menunjang semua proses pembelajaran dan dapat mempermudah siswa dalam menguasai pelajaran khususnya pada pembelajaran matematika. Bahan ajar yang ideal mampu menumbuhkan cara berifkir kritis bagi siswa sehingga pembelajaran tidak hanya berpusat pada guru saja yang menyebabkan banyaknya siswa kurang memahami atau merasa bahwa pelajaran matematika adalah pelajaran yang sangat menyeramkan.

Hasil observasi yang dilaksanakan peneliti pada tanggal, 2 November 2018 terhadap guru mata pelajaran matematika kelas IV di SDN Kunciran 7 Kota Tangerang, diketahui bahwa bahan ajar yang digunakan dalam pembelajaran matematika berisi materi dan latihan-latihan siswa, akan tetapi penerapan konsep matematika yang digunakan dalam penyusunan bahan ajar tersebut tidak sesuai dengan karakteristik siswa kelas IV penerapan konsep y ang digunakan terlalu tinggi sehingga terlihat banyak siswa yang kurang memahami isi dari materi tersebut. Dalam hal ini guru dituntut untuk lebih kreatif dan inovatif dalam menyampaikan isi pembelajaran. Dengan melihat kesenjangan yang terjadi ini maka diperlukannya pengembangan bahan ajar. Bahan ajar yang dikembangkan diharapkan mampu melatih kemandirian siswa untuk menemukan dan menerapkan konsep matematika. 
Materi yang akan dikembangkan oleh peneliti terdapat dikelas IV yang dalam penerapan konsepnya tidak sesuai dengan kebutuhan dan karakteristik sis wa kelas IV. Bahan ajar salah satu alternatif yang dapat dikembangakan untuk mempermudah siswa memahami isi materi yang terdapat didalam bahan ajar, juga dapat mengarahkan pola pikir siswa agar dapat berfikir kritis dalam pembelajaran matematika dan memban gun kemandirian siswa yang sesuai dengan karakteristik siswa kelas IV dalam mengembangkan bahan ajar.

Pembelajaran tematik merupakan kegiatan mengajar dengan memadukan materi beberapa pelajaran dalam satu tema dengan lebih menekankan terhad ap pembentukan karakteristik siswa oleh karena itu perlu dikembangkan bahan ajar tematik untuk membangun karateristik siswa secara mandiri dan peran guru sebagai fasilitator pun dapat dimaksimalkan.

Rumusan masalah, peneliti merumuskan masalah sebagai berikut, Bagaimana mengembangkan bahan ajar matematika berbasis kurikulum 2013 dengan penerapan konsep yang sesuai dengan kebutuhan dan karakteristik siswa di SD Negeri Kunciran 7 Kota Tangerang? , Bagaimana bahan ajar matematika yang dikembangkan mampu membangun kemampuan konsep matematika di Sekolah Dasar yang telah dih asilkan?. Adapun tujuan penelitian ini adalah untuk mengetahuiMengetahui langkah-langkah pengembangan bahan ajar matematika berbasis kurikulum 2013 yang sesuai dengan kebutuhan dan karakteristik siswa, Mengetahui bagaimana bahan ajar matematika yang dikembangkan mampu membangun kemampuan konsep matematika di Sekolah Dasar. Adapun spesifikasi produk yang diharapkan adalah Bahan Ajar Matematika berbasis Kurikulum 2013, Bahan Ajar ini hanya difokuskan pada pokok bahasan matematika pada Tema 7 Subtema Indahnya Keragaman di Negeriku materi Pengumpulan dan Penyajian Data pada siswa kelas IV, Bahan Ajar dalam penelitian ini dikembangkan dengan menggunakan penelitian RND. Adapun manfaat dari penelitian ini terbagi menjadi 2 yaitu teoritis dan praktis.

\section{KAJIAN PUSTAKA}

Kurikulum merupakan suatu rencana yang sengaja disusun untuk mengatur jalannya pembelajaran agar dapat mencapai tujuan pendidikan yang sesuai dengan tuntutan perkembangan jaman. Kurikulum juga sebagai rambu-rambu dalam proses 
belajar mengajar yang digunakan guru sebagai pedoman dalam menyampaik an materi agar dapat tersampaikan dengan baik sesuai dengan yang diharapkan.

Kurniasih, dkk (2014) kurikulum 2013 merupakan serentetan rangkaian penyempurnaan terhadap kurikulum yang telah dirintis tahun 2004 yang berbasis kompetensi lalu diteruskan dengan kurikulum 2006 (KTSP). Dalam pemaparannya, Menteri Pendidikan dan Kebudayaan, Muhammad Nuh, menegaskan bahwa kurikulum 2013 lebih ditekankan pada kompetensi dengan pemikiran kompetensi berbasis sikap, keterampilan, dan pengetahuan (h.7). Kurikulum 2013 merupakan kurikulum berbasis kompetensi yang disusun dalam upaya penyempurnaan pendidikan yang sengaja dirancang dan selalu mengalami perkembangan sesuai dengan perkembangan siswa dari tahun ketahununtuk mencapai sejumlah tujuan pendidikan.

Nuraeni (2017) pembelajaran tematik adalah pembelajaran terpadu yang menggunakan tema untuk mengaitkan beberapa mata pelajaran sehingga dapat memberikan pengalaman bermakna kepada peserta didik (h.27). Mengetahui hal tersebut dapat diketahui pembelajaran tematik merupakan bagian dari penerapan kurikulum 2013 dimana dalam proses pembelajaran setiap mata pelajaran disatu padukan tanpa ada batasan-batasan yang jelas yang kemudian disusun ke dalam bentuk tema.

Prastowo (2012) dalam National Center for Competency Based Training (2007), bahan ajar adalah segala bentuk bahan yang digunakan untuk membantu guru atau instruktur dalam melaksanakan proses pembelajaran dikelas (h.16). Bahan ajar merupakan bahan yang berisi materi yang digunakan guru dalam kegiatan belajar mengajar di kelas untuk mempermudah dalam menjelaskan isi materi kepada siswa.

Menurut Johnson dan Myklebust (1967:244) dalam Abdurrahman (2012), Matematika adalah bahasa simbolis yang fungsi praktisnya untuk mengekspresikan hubungan-hubungan kuantitatif dan keruangan sedangkan fungsi teoritisnya adalah untuk memudahkan berfikir (h.202). Lerner (1988:430) dalam Abdurrahman (2012) mengemukakan bahwa matematika disamping sebagai bahasa simbolis juga merupakan bahasa universal yang memungkinkan manusia memikirkan, mencatat, dan mengkomunikasikan ide mengenai elemen dan kuantitas (h.202). Kline (1981:172) dalam Abdurrahman (2012) juga mengemukakan bahwa matematika merupakan bahasa simbolis dan cirri utamanya adalah penggunaan cara bernalar dedukatif, tetapi juga 
tidak melupakan cara bernalar induktif (h.203). bahwa hakikat matematika adalah ilmu hitung yang banyak mempelajari tentang konsep dan pada hakikatnya matematika merupakan ilmu pengetahuan yang perlu dipelajari sejak usia sekolah dasar karena matematika adalah sarana berfikir yang jelas dan logis untuk memecahkan masalah dalam kehidupan sehari-hari.

\section{METODOLOGI PENELITIAN}

\section{Waktu dan Tempat}

Penelitian ini dilaksanakan di SDN Kunciran 7 Kota Tangerang yang berlokasi di Jl. Lele No.47 Kunciran indah Kec.Pinang Kota Tangerang.

\section{Model Penelitian dan Pengembangan}

Sugiyono (2015) Metode penelitian dan pengembangan atau dalam bahasa inggrisnya Research and Development metode penelitian yang digunakan untuk menghasilkan produk tertentu, dan menguji keefektifan produk tersebut. Untuk dapat menghasilkan produk tertentu digunakan penelitian yang bersifat analisis kebutuhan dan untuk menguji keefektifan produk tersebut supaya dapat berfungsi di masyarakat luas, maka diperlukan penelitian untuk menguji keefektifan produk tersebut. Jadi penelitian dan pengembangan bersifat longitudinal (bertahap bisa multy years). Penelitian Hibah Bersaing (didanai oleh Direktorat Jenderal Pendidikan Tinggi), adalah penelitian y ang menghasilkan produk, sehingga metode yang digunakan adalah metode penelitian dan pengembangan (h.407). Dalam mengembangkan suatu produk bahan ajar diperlukan suatu model pengembangan yang sesuai agar dalam prosesnya dapat menghasilkan produk bahan ajar yang berkualitas dan dapat memberikan manfaat yang signifikan terhadap para penggunanya.

Model pengembangan yang digunakan dalam penelitian ini diadaptasi dari model ADDIE (Analysis, Design, Development, Implementation, dan Evaluation) y ang dikembangkan oleh Dick and Carry (1996) untuk merancang sistem pembelajaran. Model penelitian ini adalah model prosedural, yaitu model yang bersifat deskriptif dan menggariskan pada langkah-langkah pengembangan. Winarni (2018) Langkah desain ADDIE terdiri dari lima tahap pengembangan yaitu: Analysis, Design, Development, Implementation, dan Evaluation (h. 263). 


\section{Uji Coba Produk}

Produk berupa bahan ajar perlu dilakukan pengujian untuk mengetahui kevalidan dan kepraktisan. Produk akan dikonsultasikan kepada dosen pembimbing, ahli/pakar, guru kelas dan siswa kelas IV SDN Kunciran 7 Kota Tangerang. Berikut adalah langkah-langkah dalam tahapan validasi dan evaluasi bahan ajar adalah pravalidasi, validasi ahli/pakar dan penilaian guru, dan uji coba terbatas.

\section{Desain Uji Coba}

Tahapan uji produk dalam penelitian ini berdasarkan model pengembangan ADDIE yang diawali dengan melakukan observasi dengan tujuan Analysis karakteristik dan kebutuhan siswa akan bahan ajar, selanjutnya membuat rancangan bahan ajar sesuai dengan kebutuhan siswa. Selain itu peneliti juga membuat rancangan instrument un tuk mengukur kevalidan dan kepraktisan bahan ajar yang telah dikemban gkan melalui uji ahli/pakar materi, uji ahli/pakar media, penilaian guru, dan angket respon siswa. Produk hasil pengembangan selesai direvisi, selanjutnya produk di uji cobakan dalam uji coba terbatas melalui proses pembelajaran pada siswa kelas IV SDN Kunciran 7 Kota Tangerang setelah itu peneliti memberikan angket respon siswa untuk mengukur kepraktisan produk dan kemudian merevisi produk sesuai dari masukan-masukan siswa yang diperoleh dari angket respon siswa. Bahan ajar yang telah dievaluasi dan telah memenuhi kriteria kevalidan dan kepraktisan sudah menjadi sebuah produk bahan ajar yang siap untuk digunakan dalam proses pembelajaran.

\section{Instrumen Pengumpulan Data}

Sugiyono (2017) Instrumen adalah berbagai alat ukur yang digunakan secara sistematis untuk pengumpulan data, seperti test, kuesioner, dan pedoman wawancara (h.156). Dalam hal ini peneliti menggunakan instrumen pengumpulan data menggunakan skala likert dengan alternatif jawaban: sangat baik, baik, cukup, kurang dan sangat kurang. 


\section{HASIL DAN PEMBAHASAN}

\section{Penyajian Data Uji Coba}

\section{Tahap Analisis (Analysis)}

Dalam tahap ini peneliti mengidentifikasi kurikulum yang digunakan di SDN Kunciran 7 Kota Tangerang adalah kurikulum 2013. Kemudian peneliti dapat mengidentifikasi Kompetensi Inti, Kompetensi dasar serta indikator pencapaian kompetensi yang dibutuhkan untuk pengembangan bahan ajar matematika.

\section{Tahap Perancangan (Design)}

Sebelum itu peneliti juga mengumpulkan gambar-gambar yang berkaitan dengan materi untuk digunakan di dalam bahan ajar matematika. Peneliti memperoleh gambar-gambar tersebut dari internet. Draf bahan ajar yang telah ada kemudian diberikan penilaian terlebih dahulu oleh para ahli yaitu ahli materi dan ahli media, untuk selanjutnya hasilnya digunakan untuk penyempurnaan pengembangan produk. Berikut adalah draf bahan ajar yang belum di validasi oleh para ahli sebagai berikut adalah cover, daftar isi, petunjuk penggunaan buku, kompetensi inti dan kompetensi dasar, indicator, tujuan pembelajaran, materi dan latihan soal.

\section{Tahap Pengembangan (Development)}

Produk awal yang telah dikonsultasikan kepada dosen pembimbing dan telah dilakukan revisi sesuai saran dan masukan dosen pembimbing, kemudian dapat melanjutkan ke tahap pengembangan untuk mendapatkan saran atau validasi dari para ahli diantaranya ahli materi, ahli media, dan ahli pendidikan (pengguna) untuk mendapatkan hasil akhir dari produkbahan ajar matematika. Langkahlangkah yang dilakukan peneliti dalam tahap pengembangan ini adalah : validitas ahli materi, validitas ahli media, dan validitas pengguna (guru).

\section{Tahap Implementasi (Implementation)}

Setelah bahan ajar dilakukan uji kevalidan oleh para ahli maka untuk selanjutn ya bahan ajar dapat di uji cobakan dalam bentuk kelompok kecil yaitu uji coba dalam bentuk peroses pembelajaran. Uji coba ini dilakukan di SD Negeri Kunciran 7 
Kota Tangerang dengan subyek Penelitian siswa kelas IV. Uji coba ini diikuti oleh 30 siswa. Pada awal pembelajaran peserta didik dibagi menjadi empat kelompok. Masing-masing kelompok terdiri dari 7-8 orang dengan kemampuan matematika yang heterogen. Kemudian peneliti membagikan bahan ajar agar dapat mereka pelajari. Strategi belajar kelompok yang peneliti lakukan bertujuan agar peserta didik saling bekerja sama dan bertukar pikiran apabila ada siswa yang merasa kesulitan dalam memahami materi.

\section{Tahap Evaluasi}

Tahap Evaluasi merupakan tahap akhir yang dilakukan dalam penelitian pengembangan yang sesuai dalam pengembangan ADDIE. Tahap Evaluasi melipui revisi akhir terhadap produk yang telah disusun sesuai dengan komentar dan saran dari para ahli (ahli materi dan ahli media), ahli pendidikan (pengguna), dan angket respon peserta didik dan juga menganalisis data yang telah didapatkan dari para ahli materi dan media, ahli pengguna, dan angket respon peserta didik.

Berikut ini adalah langkah-langkah dalam menganalisis produk yang dikembangkan sebagai berikut:

\section{Analisis Kevalidan}

$$
\begin{aligned}
& \text { Tingkatkevalidan }=\frac{\text { Skor yang diperoleh }}{\text { Skor Maksimal }} \times 100 \% \\
& =\frac{114}{190} \times 100 \% \\
& =60 \%
\end{aligned}
$$

Berdasarkan penilaian dari ahli media maka dapat dilakukan perhitungan tingkat kevalidan sebagai berikut:

Tingkatkevalidan $=\frac{\text { Skor yang diperoleh }}{\text { Skor Maksimal }} \times 100 \%$

$=\frac{85}{100} \times 100 \%$

$=85 \%$

Berdasarkan penilaian dari Validator ahli materi memperoleh presentase $60 \%$ dengan kategori kurang Valid dan disarankan tidak dipergunakan karena perlu revisi sesuai saran dan komentar dari validator. Sedangkan dari Validator ahli 
media memperoleh persentase $85 \%$ dengan kategori Cukup Valid, atau dapat digunakan namun perlu revisi kecil sesuai komentar dan saran dari ahli media. Dengan demikian dapat disimpulkan bahwa kevalidan bahan ajar dikatakan cukup valid namun masih memerlukan revisi sesuai saran dan komentar dari para validator.

\section{Analisis Kepraktisan}

$$
\begin{aligned}
& \text { Tingkatkepraktisan }=\frac{\text { Skor yang diperoleh }}{\text { Skor Maksimal }} \times 100 \% \\
& =\frac{48}{50} \times 100 \% \\
& =96 \%
\end{aligned}
$$

Berdasarkan penilaian kepraktisan dari ahli pendidikan memperoleh persentase $96 \%$ dengan kategori Sangat Valid, dan dari angket re spon peserta didik memperoleh persentase $81 \%$ dengan kategori sangat valid. Dengan demikian dapat disimpulkan bahwa bahan ajar kepraktisan pada bahan ajar yang telah dikembangkan dikatakan sangat valid atau tidak revisi.

\section{Analisis Keefektifan}

$$
\begin{aligned}
& \text { Ketuntasan }(p)=\frac{\text { jumlaH siswa yang tuntas }}{\text { jumla siswa yang mengikuti tes }} \times 100 \% \\
& =\frac{27}{30} \times 100 \% \\
& =90 \%
\end{aligned}
$$

Berdasarkan data dari hasil belajar siswa setelah mendapatkan pelajaran dengan menggunakan bahan ajar yang telah dikembangkan memperoleh persentase $90 \%$ dengan kategori sangat valid atau sangat efektif sehingga dapat disimpulkan bahwa bahan ajar yang telah dikembangkan sangat efektif untuk pembelajaran dikelas.

\section{A. Revisi Produk}

Berdasarkan data hasil analisis di atas maka produk bahan ajar yang telah dikembangkan memerlukan beberapa revisi sesuai dengan saran dan komentar dari para ahli atau pakar, guru matematika dan peserta didik. 


\section{KESIMPULAN}

Berdasarkan hasil penelitian yang telah diuraikan, maka dapat diambil kesimpulan sebagai berikut: Pengambangan Bahan Ajar Matematika Berbasis Kurikulum 2013 dilakukan dengan menggunakan prosedur pengem bangan ADDIE yang terdiri atas tahap analysis (analisis), tahap design (perancangan), tahap development (pengembangan), tahap implementation (implementasi), tahap evaluation (evalusai), bahan ajar matematika yang telah dikembangkan yang kemudian ditinjau dari aspek kevalidan, Kepraktisan dan Keefektifan yaitu penilaian yang dilakukan oleh ahli materi, ahli media, ahli pendidikan dan ketuntasan hasil belajar siswa terhadap bahan ajar yang telah dikembangkan oleh peneliti masingmasing dari para ahli memperoleh skor rata-rata 60\%, 85\%, 96\% dan 90\% yang termasuk dalam kategori valid. Dapat disimpulkan bahwa bahan ajar matematika berbasis kurikulum 2013 termasuk dalam kategori valid dan tidak ada revisi.

\section{SARAN}

1. Guru perlu mengembangkan bahan ajar karena dapat memberikan dorongan pada siswa untu semangat dalam belajar.

2. Guru perlu mengembangkan bahan ajar sendiri agar lebih memudahkan bagi guru maupun siswa untuk mencapai tujuan pembelajaran karena bahan ajar yang dikembangkan disesuaikan dengan karakteristik dan kebutuhan siswa yang berbeda-beda pada setiap daerah.

3. Bagi pembaca yang tertarik dengan penelian ini dapat mengembangkan bahan ajar berbasis kurikulum 2013 yang lebih baik lagi dari yang sebelumnya atau pembaca dapat mengembangkan bahan ajar berbasis model pembelajaran yang lain.

\section{DAFTAR PUSTAKA}

Abdurrahman, Mulyono. (2012). Anak Berkesulitan Belajar. Jakarta: Rineka Cipta.

Ahmadi, Lif Khoiru, dkk. (2011). Strategi Pembelajaran Sekolah Terpadu. Jakarta: PT. Prestasi Pustakarya. 
Akbar, Sa'dun. (2013). Instrumen Perangkat Pembelajaran. Bandung: PT. Remaja Rosdakarya.

---, dkk. (2016). Implementasi Pembelajaran Tematik di Sekolah Dasar. Bandung: PT. Remaja Rosdakarya.

Desmita, (2014). Psikologi Perkembangan Peserta Didik. Bandung: PT. Remaja Rosdakarya.

Hajar, Ibnu. (2013). Panduan Lengkap Kurikulum Tematik. Jogjakarta: Diva Press.

Heruman. (2017). Model Pembelajaran Matematika di Sekolah Dasar. Bandung: PT. Remaja Rosdakarya.

Kurniasih, Imas, dkk. (2014). Panduan Membuat Bahan Ajar Buku Teks Pelajaran. Surabaya: Kata Pena.

-----. (2014).Sukses Mengimplementasikan Kurikulum 2013. Surabaya: Kata Pena.

Nuraeni, Yeni. (2017). Bahan Ajar Pembelajaran Tematik. Bogor: Cahaya Pelajar.

Prastowo, Andi. (2013). Panduan Kreatif membuat Bahan Ajar Inovatif. Jogjakarta: DIVA Press.

Sugiyono. (2015). Metode Penelitian Pendidikan. Bandung: Alfabet.

. (2017). Metode Penelitian dan Pengembangang. Bandung: alfabeta.

Suryani, Nunuk, dkk. (2018). Media Pembelajaran Inovatif dan Pengembangannya. Bandung: PT. Remaja Rosdakarya.

Susanto, ahmad. (2016). Teori Belajar dan Pembelajaran. Jakarta: Prenada Media Group.

Tim Pengembang MKDP Kurikulum dan Pembelajaran. (2017). Kurikulum dan Pembelajaran. Depok: Rajawali Pres.

Torar, Lexy. (2010). Evaluasi Matematika. Jakarta: Trans Mandiri abadi.

Winarni, Endang Widi. (2018). Teori dan Praktik Penelitian Kuantitatif, Kualitatif.

Penelitian Tindakan Kelas (PTK), Research and Development (R\&D). Jakarta: Bumi Aksara, PT. Cahaya Prima Sentosa. 